International Journal of Automotive and Mechanical Engineering (IJAME)

ISSN: 2229-8649 (Print); ISSN: 2180-1606 (Online); Volume 8, pp. 1207-1217, July-December 2013

CUniversiti Malaysia Pahang

DOI: http://dx.doi.org/10.15282/ijame.8.2013.11.0099

\title{
OPTIMUM THICKNESS OF WALL INSULATIONS AND THEIR THERMAL PERFORMANCE FOR BUILDINGS IN MALAYSIAN CLIMATE
}

\author{
F. Basrawi ${ }^{1}$, H. Ibrahim ${ }^{1}$, M.Y. Taib ${ }^{1}$ and G.C. Lee ${ }^{1}$ \\ ${ }^{1}$ Faculty of Mechanical Engineering, University Malaysia Pahang \\ 26600 Pekan, Pahang, Malaysia \\ Phone: +609-424-6350; Fax: +609-424-2202 \\ Email: mfirdausb@ump.edu.my
}

\begin{abstract}
This study clarifies the optimum thickness of insulation materials for buildings by using the life cycle cost analysis. Common external walls including clay brick, sand cement brick and concrete in the Malaysian climate were studied. Various types of buildings including office, residential and hotel were considered. Optimum thicknesses of insulation materials including rockwool, fiberglass and extruded polystyrene were clarified. It was found that the appropriate insulation thickness in Malaysia is in the range of 18-126 mm. Different operating hours and inside-outside temperatures have a significant effect on the life cycle net saving. However, different external wall types have a slight effect on the life cycle net saving. A general index, cost/k for selecting the most cost-effective insulation material was also introduced. The material that has a higher cost/k value but a lower cost compared to other materials has the highest net saving. From all the insulation materials studied, fiberglass urethane was the most costeffective.
\end{abstract}

Keywords: Insulation material; energy and building; optimum thickness; life cycle cost.

\section{INTRODUCTION}

The world is continuously facing energy depletion and environmental threats and therefore the development of new energy sources and energy-saving techniques is becoming more important. It was reported that $15 \%$ of all electricity produced in the world is used for refrigeration and air-conditioning, and energy consumption for airconditioning has been estimated to be $45 \%$ of the whole household and commercial sector (Choudhury et al., 2010). It was also reported that $21 \%$ of electricity consumption in the residential sector is used for air-conditioning in Malaysia (Mahlia \& Chan, 2011). The increased demand for air-conditioning is due to the increasing population and increasing living standards, especially in developing countries (Zhai \& Wang, 2010; Henning, 2007; Pons et al., 1999). Furthermore, the trend in building design to use opaque surfaces for the building walls also contributes to the increased demand for airconditioning (Zhai \& Wang, 2010; Henning, 2007). Air-conditioning demand can be reduced by the installation of proper insulation. Insufficiently thick insulation will be less effective, and excessively thick insulation will be uneconomic. Thus, many studies have been carried out on the optimum thickness of insulation materials in different regions (Mahlia \& Iqbal, 2010; Yildiz et al., 2008; Yu et al., 2009; Al-Khawaja, 2004; Ozel, 2012, 2013; Axaopoulos, Axaopoulos, \& Gelegenis, 2014). The optimum thickness of insulation material is also affected by the external wall and type of buildings. There are studies on the optimum insulation thickness for a tropical region by 
Mahlia et al. (2007) and Chirarattananon, Hien, and Tummu (2012), but only one type of building or one type of wall was considered in these studies. Thus, the objective of this study is to clarify the optimum thickness of insulation materials in various buildings and various external walls. Moreover, the most cost-effective insulation material was also clarified by a general index that consists of two important characteristics of insulation materials, the ratio of cost to the thermal conductivity of the insulation material. The effects of the building type and external wall type on insulation materials and thicknesses were also clarified. Six types of insulation material were studied in four types of buildings including residential, office and hotels, and three types of external walls including clay brick, sand cement brick and concrete. Optimum thickness was studied using life cycle cost analysis, and the payback period and net saving were also clarified.

\section{MATERIALS AND METHODS}

\section{Structure of External Walls}

Clay brick, sand cement brick and concrete, which are commonly used for external walls in Malaysia, were studied. Details of the walls are shown in Figure 1 and Table 1. In general, clay brick has better thermal resistance because it has lower thermal conductivity, but it costs more. The thickness of the external walls was set on the basis of standard and common practice (Public Works Department, 2005).

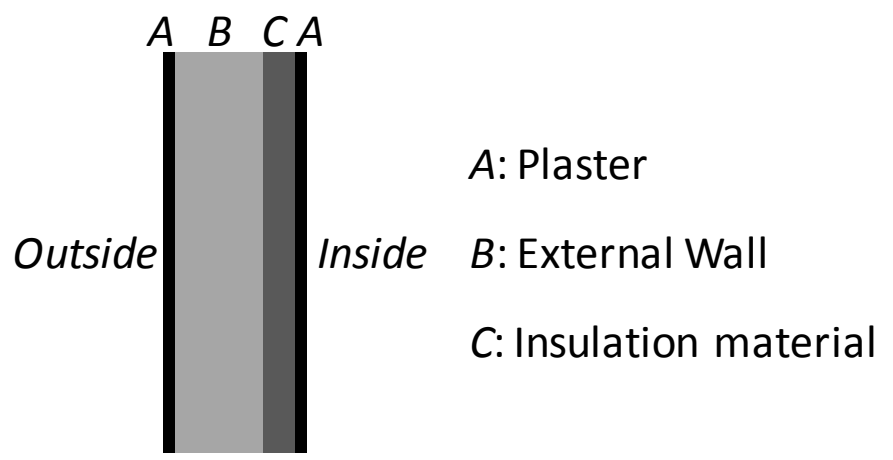

Figure 1. Layers of the wall

Table 1. Thermal conductivity and thickness of every layer

\begin{tabular}{ccc}
\hline Layer & $\begin{array}{c}\text { Thermal conductivity } \\
{\left[10^{-3} \mathrm{~kW} / \mathrm{mK}\right]}\end{array}$ & $\begin{array}{c}\text { Thickness } \\
{[\mathrm{m}]}\end{array}$ \\
\hline External Wall & & \\
Clay brick & 0.711 & 0.104 \\
Sand cement brick & 1.000 & 0.114 \\
Concrete & 0.546 & 0.100 \\
Plaster & 1.500 & 0.019 \\
\hline
\end{tabular}




\section{Life Cycle Cost and Optimum Insulation Thickness}

\section{Heat Transfer Through the Wall}

Heat losses to the environment through the wall per unit area $q_{/ A}$ can be calculated by Eq. (1):

$$
q_{/ A}=U\left(t_{\text {out }, \text { ave }}-t_{\text {in }}\right)
$$

where $t_{\text {in }}$ is assumed to be $21\left[{ }^{\circ} \mathrm{C}\right], t_{\text {out,ave }}$ depends on the operation time of the building, and the overall thermal coefficient $U\left[\mathrm{~kW} / \mathrm{m}^{2} \mathrm{~K}\right]$ can be calculated by Eq. (2):

$$
U=\frac{1}{\left(\frac{1}{h_{1}}+\frac{x_{1}}{k_{1}}+\frac{x_{2}}{k_{2}}+\frac{x_{i n s}}{k_{i n s}}+\frac{x_{4}}{k_{4}}+\frac{1}{h_{2}}\right)}=\frac{1}{\left(R_{\text {total }}+\frac{x_{i n s}}{k_{\text {ins }}}\right)}
$$

where both $h_{1}$ and $h_{2}$ are assumed to be $0.0047\left[\mathrm{~kW} / \mathrm{m}^{2} \mathrm{~K}\right], x, k$ and $R$ represent thickness, thermal conductivity and thermal resistance, respectively. Subscripts 1, 2 or 4, ins and total represent the plaster layer, external wall layer, insulation and total value, respectively. Details of the average temperature difference, operating time and annual demand hours are shown in Table 2. Six insulation materials that are available in Malaysia are studied and details of their thermal conductivity and cost are shown in Table 3.

Table 2. Details of the average temperature difference, operating time and annual demand hours.

\begin{tabular}{lcrrr}
\hline Building type & $\begin{array}{c}\text { Average } \\
\text { temperature } \\
\text { difference } \\
{\left[{ }^{\circ} \mathrm{C}\right]}\end{array}$ & \multicolumn{2}{c}{$\begin{array}{c}\text { Daily operating hour } \\
\text { (Total operating hours) } \\
{[\mathrm{h}]}\end{array}$} & $\begin{array}{c}\text { Annual } \\
\text { demand hours } \\
{[\mathrm{h}]}\end{array}$ \\
\hline Office & 8.0 & 8am-5pm & $(10 \mathrm{~h})$ & 2086 \\
Residential & 4.6 & $1 \mathrm{am}-7 \mathrm{am}, 7 \mathrm{pm}-12 \mathrm{pm}(13 \mathrm{~h})$ & 4745 \\
Shop/ restaurant & 7.2 & $7 \mathrm{am}-10 \mathrm{pm}$ & $(18 \mathrm{~h})$ & 5840 \\
Hotel/ convenience store & 6.2 & $1 \mathrm{am}-12 \mathrm{pm}$ & $(24 \mathrm{~h})$ & 8760 \\
\hline
\end{tabular}

Table 3. Details of the six insulation materials available in Malaysia

\begin{tabular}{lcc}
\hline \multicolumn{1}{c}{ Insulation materials } & $\begin{array}{c}\text { Thermal conductivity } \\
{\left[10^{-3} \mathrm{~kW} / \mathrm{mK}\right]}\end{array}$ & $\begin{array}{c}\text { Price } \\
{\left[\$ / \mathrm{m}^{3}\right]}\end{array}$ \\
\hline Rock wool & 0.034 & 175 \\
Fiberglass & 0.033 & 304 \\
Urethane & 0.024 & 262 \\
Fiberglass urethane & 0.021 & 214 \\
Perlite & 0.054 & 98 \\
Extruded polystyrene & 0.029 & 182 \\
(Mahlia \& Iqbal, 2010) & & \\
\hline
\end{tabular}


Finally, the annual energy required for space cooling per unit area $E_{/ A}$ can be calculated by Eq. (3):

$$
E_{/ A}=\frac{q_{/ A}}{C O P} A D H
$$

where $C O P$ is assumed to be 2.93. Eq. (3) can also be expressed as the following equation:

$$
E_{/ A}=\frac{\left(t_{\text {out }, \text { ave }}-t_{\text {in }}\right) A D H}{\left(R_{\text {total }}+\frac{x_{\text {ins }}}{k_{\text {ins }}}\right) C O P}
$$

\section{Cost Analysis and Optimum Thickness}

The sum of the cost of the fuel consumed and the initial cost of insulation material can be used as a measurement to calculate the optimum thickness. In general, if the insulation thickness increases, the cost of the insulation material will increase and the cost of electricity will decrease. The cost of the insulation per unit area $C_{\text {ins/A }}$ can be calculated by the following equation:

$$
C_{i n s / A}=C_{i n s} \cdot x_{i n s}
$$

where values of $C_{i n s}$ are already shown in Table 3 . The cost of electricity per unit area, $C_{\text {ele/A }}$ can be calculated by the following equation:

$$
C_{\text {ele } / A}=P W F \cdot E_{/ A} \cdot C_{e l e}
$$

where $C_{\text {ele }}$ is assumed to be $0.078 \$ / \mathrm{kWh}$ and $P W F$ is the factor of the present worth of the fuel consumed for the entire life cycle and can be calculated as Eq. (7):

$$
P W F=\frac{(1+i)}{(d-i)}\left[1-\left(\frac{1+i}{1+d}\right)^{L T}\right]
$$

where $d$ is the interest rate [-], $i$ is the inflation rate [-] and $L T$ is the life time [year]. $d$ and $i$ are assumed to be 0.064 and 0.023 , respectively, and $L T$ is assumed to be 20 years.

The total cost per unit area, $T C_{/ A}$ can be obtained by summing $C_{i n s / A}$ and $C_{\text {ele/A }}$ as expressed by Eq. (8). It can also be expressed as Eq. (9) by substituting $E_{/ A}$ with Eq. (4):

$$
T C_{/ A}=C_{\text {ele } / A}+C_{i n s / A}
$$




$$
T C_{/ A}=P W F \cdot \frac{\left(t_{\text {out }, a v e}-t_{i n}\right) \cdot A D H}{\left(R_{\text {total }}+\frac{x_{i n s}}{k_{\text {ins }}}\right) \cdot C O P} \cdot C_{\text {ele }}+C_{\text {ins }} \cdot x_{i n s}
$$

As shown in Figure 2, if thickness is the only variable, when insulation thickness increases the total cost decreases until it reaches the lowest value, and then the total cost increases again. The optimum thickness is obtained at the lowest value of total cost. By differentiating Eq. (9) with respect to $x_{i n s}$, and by assuming the equation is equal to 0 , which indicates the lowest value of the curve, $x_{\text {opt }}$ can be obtained by the following equation:

$$
x_{\text {opt }}=\left(k_{\text {ins }} \cdot \frac{\left(t_{\text {out }, \text { ave }}-t_{\text {in }}\right) \cdot A D H}{C O P \cdot C_{i n s}} \cdot C_{\text {ele }} \cdot P W F\right)^{1 / 2}-R_{\text {total }} \cdot k_{\text {ins }}
$$

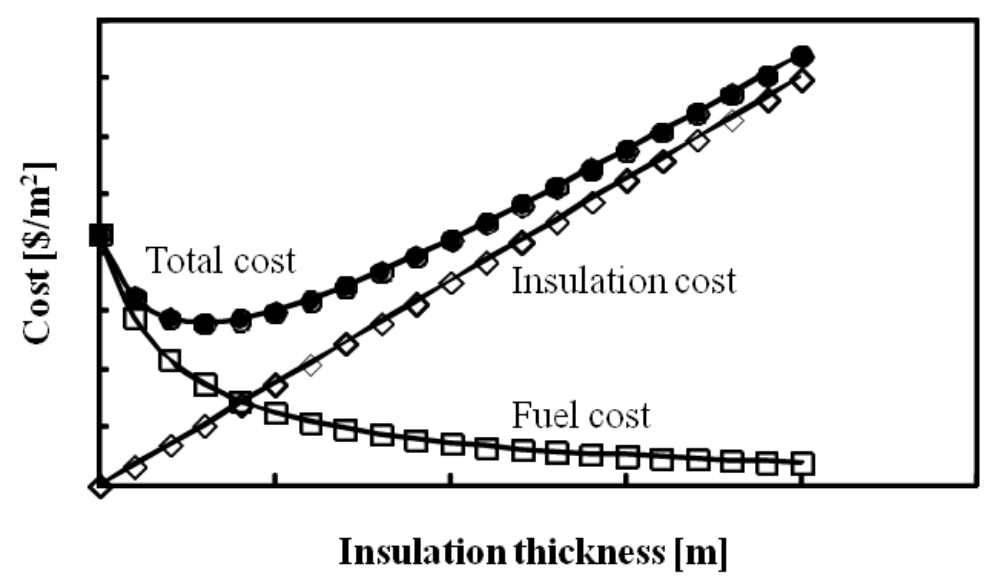

Figure 2. Relationship of total cost, insulation cost and fuel cost.

Net saving per unit area $N S_{/ A}$ can be calculated by Eq. (11). The amount of electricity saved can be calculated by the difference between the case with insulation and the case without insulation $\left(C_{\text {ele/A,unins }}-C_{\text {ele/A,ins }}\right)$. Over time, the saved amount will increase until it can cancel out the insulation cost $\left(C_{\text {ins/A }}\right)$ and the net saving will be equal to 0 . This means that the investment is paid back in that particular year. Thus, by assuming the net saving is equal to zero, and by substituting PWF with Eq. (7), the payback period $P B P$ can be derived as Eq. (12):

$$
\begin{aligned}
N S_{/ A} & =C_{\text {ins } / A}-\left(C_{\text {ele } / A, \text { unins }}-C_{\text {ele } / A, \text { ins }}\right) \\
& =C_{\text {ins }} \cdot x_{\text {opt }}-P W F \cdot \frac{\Delta t \cdot A D H \cdot C_{\text {ele }}}{C O P}\left(\frac{1}{R_{\text {total }}}-\frac{1}{R_{\text {total }}+\frac{x_{o p t}}{k_{\text {ins }}}}\right)
\end{aligned}
$$




$$
P B P=\frac{\log _{10}\left(1-\frac{C_{\text {ins }} \cdot C O P \cdot R_{\text {total }} \cdot k\left(R_{\text {total }}+\frac{x_{\text {opt }}}{k_{\text {ins }}}\right) \cdot(d-i)}{\left(t_{\text {out }, \text { ave }}-t_{\text {in }}\right) \cdot A D H \cdot C_{\text {ele }} \cdot(1+i)}\right)}{\log _{10}\left(\frac{1+i}{1+d}\right)}
$$

\section{RESULTS AND DISCUSSION}

\section{Optimum Insulation, Payback Period and Net Saving}

Table 4 shows the optimum thickness $x_{\text {opt }}$, payback period (PBP) and net saving (NS) for a 20 year life cycle for all insulation materials for all types of building when clay brick was used as the external wall. It was found that the office building that had the least operation time had the thinnest $x_{\text {opt }}$ for all insulation materials, whereas the hotel and convenience store that had longer operation times had the thickest $x_{\text {opt }}$. It was also found that the thinnest insulation material was fiberglass in the office, $0.019 \mathrm{~m}$, whereas the thickest insulation material was perlite in the hotel or convenience store, $0.124 \mathrm{~m}$. Different types of building basically result in different annual demand hours $(A D H)$ and average outside temperature. The effects of $A D H$ and the average temperature difference on $P B P$ and $N S$ are shown in Figure 3 and Figure 4, respectively. It was found that the average temperature difference and $A D H$ significantly affect the performance of the wall. If the temperature difference and operating times are too low, the insulation has a negative value of $N S$. When $A D H$ is 8760 , which means that a building operates 24 hours a day throughout the year, rock wool can save up to $48 \$ / \mathrm{m}^{2}$. Table 5 shows the optimum thickness $x_{\text {opt }}$, payback period $(P B P)$ and net saving $(N S)$ for a 20 year life cycle for all types of external wall when the office building was used as the type of building. It was found that there were no big differences of $x_{o p t}, P B P$ and $N S$ when different external walls were used. Concrete had the thinnest $x_{\text {opt }}$, whereas sand cement brick had the thickest $x_{\text {opt }}$. This is because sand cement brick has higher thermal conductivity, which results in lower thermal resistance and therefore a need for thicker insulation.

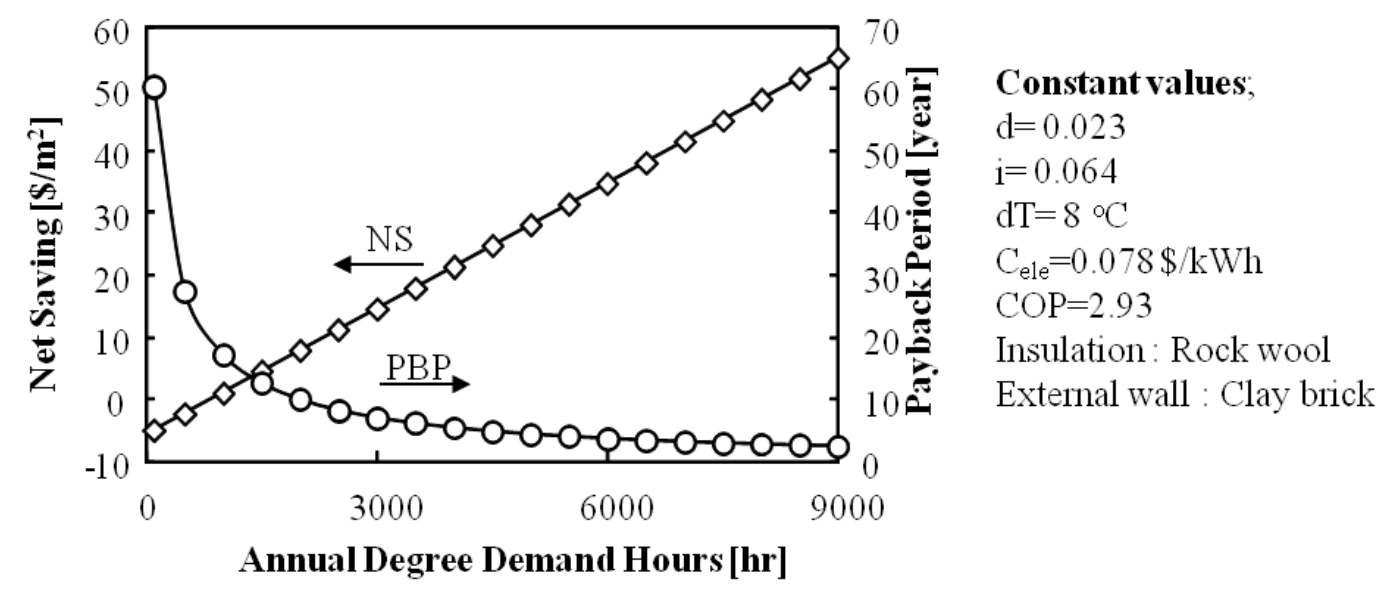

Figure 3. Effect of annual demand hours on the payback period and net saving. 


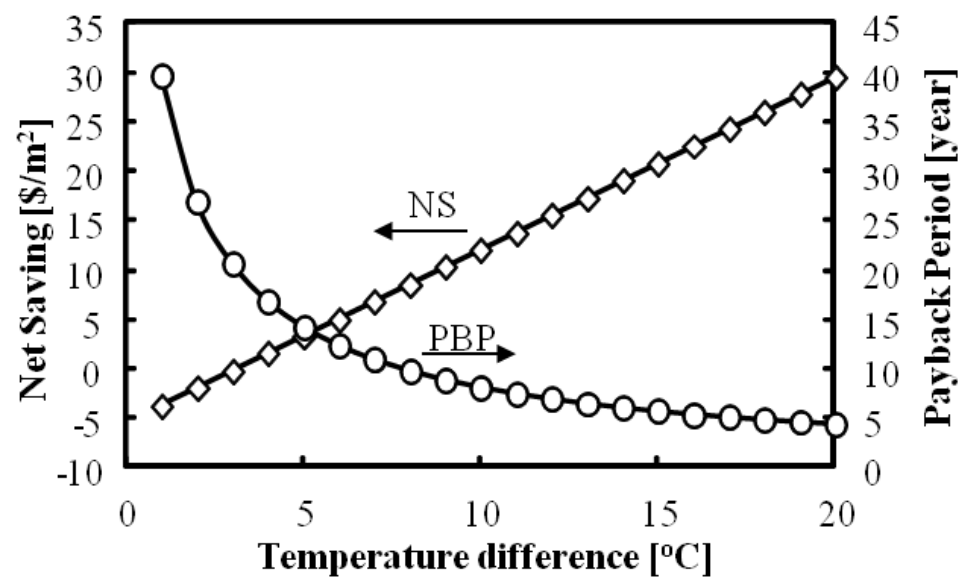

Constant values;

$\mathrm{d}=0.023$

$\mathrm{i}=0.064$

$\mathrm{ADH}=2086 \mathrm{~h}$

$\mathrm{C}_{\mathrm{ele}}=0.078 \$ / \mathrm{kWh}$

$\mathrm{COP}=2.93$

Insulation : Rock wool

External wall : Clay brick

Figure 4. Effect of average temperature difference on the payback period and net saving.

Table 4. Results for optimum thickness, payback period and net saving when clay brick was used as the external wall.

\begin{tabular}{|c|c|c|c|c|c|}
\hline & & Material & $\begin{array}{c}\text { Optimum } \\
\text { thickness, } \mathrm{x}_{\mathrm{op}} \\
{[\mathrm{m}]}\end{array}$ & $\begin{array}{c}\text { Payback } \\
\text { period, PBP } \\
\text { [years] }\end{array}$ & $\begin{array}{c}\text { Net saving, } \\
\mathrm{NS} \\
{\left[\$ / \mathrm{m}^{2}\right]} \\
\end{array}$ \\
\hline & & Rockwool & 0.031 & 9.78 & 8.5 \\
\hline & & Fiberglass & 0.019 & 12.09 & 5.6 \\
\hline & $\circlearrowright$ & Urethane & 0.021 & 10.01 & 8.2 \\
\hline & 0 & Fiberglass urethane & 0.024 & 8.69 & 10.0 \\
\hline & & Perlite & 0.055 & 9.31 & 9.2 \\
\hline & & Extruded polystyrene & 0.030 & 9.30 & 9.2 \\
\hline & & Rockwool & 0.039 & 8.57 & 13.0 \\
\hline & ]$. & Fiberglass & 0.024 & 10.87 & 9.2 \\
\hline$\cdot \stackrel{0}{=}$ & $\overline{0}$ & Urethane & 0.026 & 8.96 & 12.6 \\
\hline$\frac{n}{\lambda}$ & $\cdot \frac{\sigma}{\pi}$ & Fiberglass urethane & 0.029 & 7.76 & 14.8 \\
\hline $\overrightarrow{\vec{\sigma}}$ & & Perlite & 0.067 & 8.32 & 13.8 \\
\hline & & Extruded polystyrene & 0.036 & 8.31 & 13.8 \\
\hline $\bar{\pi}$ & & Rockwool & 0.062 & 6.57 & 33.2 \\
\hline 3 & & Fiberglass & 0.042 & 8.24 & 27.0 \\
\hline$\sigma$ & 童 & Urethane & 0.042 & 6.73 & 32.6 \\
\hline$\stackrel{\oplus}{x}$ & च & Fiberglass urethane & 0.046 & 5.80 & 36.1 \\
\hline & & Perlite & 0.106 & 6.24 & 34.4 \\
\hline & & Extruded polystyrene & 0.057 & 6.23 & 34.4 \\
\hline & & Rockwool & 0.073 & 5.90 & 45.6 \\
\hline & ర్ & Fiberglass & 0.050 & 7.42 & 38.3 \\
\hline & Ð & Urethane & 0.050 & 6.04 & 44.9 \\
\hline & $\stackrel{0}{I} \stackrel{0}{D}$ & Fiberglass urethane & 0.054 & 5.20 & 49.0 \\
\hline & 0 & Perlite & 0.124 & 5.60 & 47.0 \\
\hline & & Extruded polystyrene & 0.067 & 5.59 & 47.1 \\
\hline
\end{tabular}


Different types of external wall basically result in different thermal conductivity and wall thickness. Since the wall thickness is usually fixed according to the standard, only thermal conductivity will affect the thermal performance of the wall. The effects of thermal conductivity on the $P B P$ and $N S$ are shown in Figure 5, where, for a range of thermal conductivity for common walls, only a slight change was found. Rock wool used with an external wall that has lower thermal conductivity, such as clay brick $(0.00071 \mathrm{~kW} / \mathrm{mK})$, resulted in less $N S$ than when it was used with an external wall with higher thermal conductivity, such as sand cement brick $(0.0010 \mathrm{~kW} / \mathrm{mK})$.

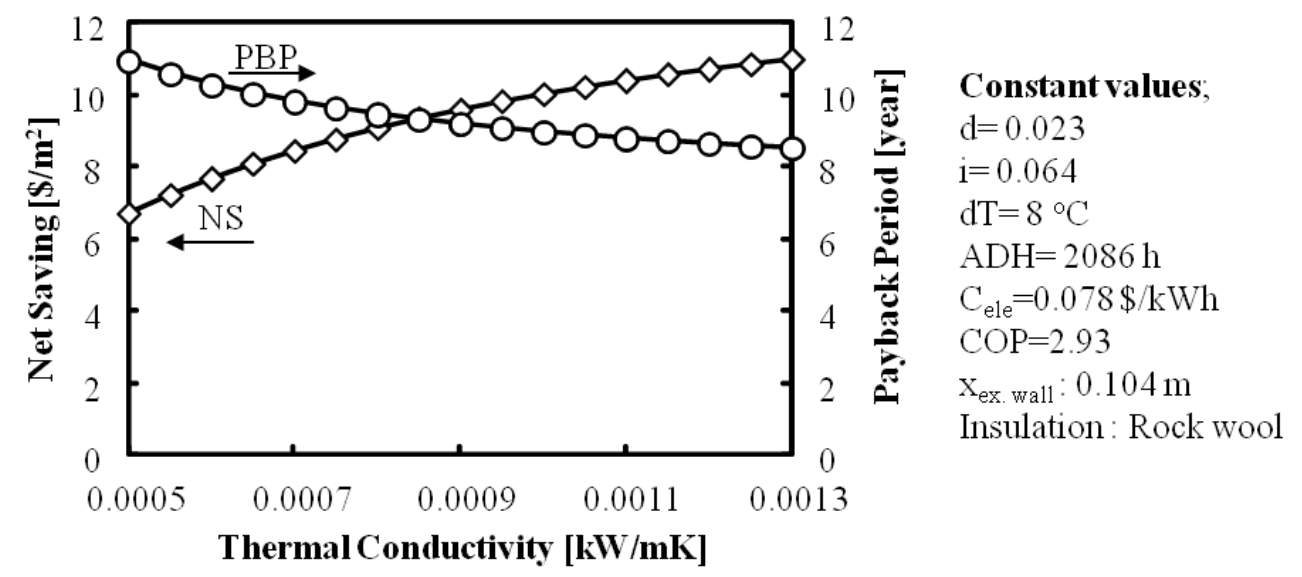

Figure 5. Effect of thermal conductivity on the payback period and net saving.

Table 5. Results for optimum thickness, payback period and net saving when office building was used as the building type.

\begin{tabular}{|c|c|c|c|c|c|}
\hline & & Material & $\begin{array}{l}\text { Optimum } \\
\text { thickness, } \mathrm{x}_{\mathrm{op}} \\
{[\mathrm{m}]}\end{array}$ & $\begin{array}{c}\text { Payback } \\
\text { Period, PBP } \\
\text { [years] }\end{array}$ & $\begin{array}{c}\text { Net saving, } \\
\text { NS } \\
{[\$ / \mathrm{m} 2]}\end{array}$ \\
\hline \multirow{18}{*}{ 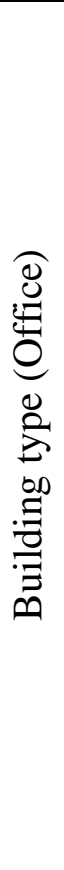 } & \multirow{6}{*}{$\begin{array}{l}\frac{y}{0} \\
\frac{0}{0} \\
\frac{\vec{J}}{0}\end{array}$} & Rockwool & 0.031 & 9.78 & 8.5 \\
\hline & & Fiberglass & 0.019 & 12.09 & 5.6 \\
\hline & & Urethane & 0.021 & 10.01 & 8.2 \\
\hline & & Fiberglass urethane & 0.024 & 8.69 & 10.0 \\
\hline & & Perlite & 0.055 & 9.31 & 9.2 \\
\hline & & Extruded polystyrene & 0.030 & 9.30 & 9.2 \\
\hline & \multirow{6}{*}{ 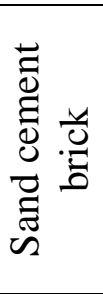 } & Rockwool & 0.033 & 9.34 & 9.7 \\
\hline & & Fiberglass & 0.020 & 11.57 & 6.6 \\
\hline & & Urethane & 0.022 & 9.55 & 9.3 \\
\hline & & Fiberglass urethane & 0.025 & 8.29 & 11.2 \\
\hline & & Perlite & 0.057 & 8.89 & 10.3 \\
\hline & & Extruded polystyrene & 0.031 & 8.88 & 10.3 \\
\hline & \multirow{6}{*}{ 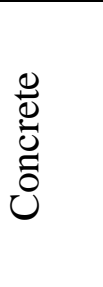 } & Rockwool & 0.030 & 10.28 & 7.4 \\
\hline & & Fiberglass & 0.018 & 12.66 & 4.6 \\
\hline & & Urethane & 0.020 & 10.50 & 7.1 \\
\hline & & Fiberglass urethane & 0.023 & 9.13 & 8.9 \\
\hline & & Perlite & 0.053 & 9.78 & 8.1 \\
\hline & & Extruded polystyrene & 0.029 & 9.77 & 8.1 \\
\hline
\end{tabular}


As shown in Table 4 and Table 5, it was also found that fiberglass had the thinnest $x_{o p t}$, whereas perlite had the thickest $x_{o p t}$ for any condition. From the result obtained, the range of $x_{\text {opt }}$ for all conditions studied was $0.018-0.126 \mathrm{~m}$. The same tendency was found for $N S$, as fiberglass had the lowest $N S$, whereas perlite had higher $N S$. However, NS for fiberglass urethane was found to be the highest in any conditions. This phenomenon will be explained in the following section.

\section{Relation Between Cost/K and Net Saving}

Two important characteristics of insulation materials that are usually considered for their selection are cost and thermal conductivity. Therefore, it is important to know how they affect the net saving for the entire life cycle. This will help in selecting the most cost-effective insulation material. Figure 6 shows the cost and Cost/k value for every insulation material. Cost/k will be a beneficial index because it only consists of the two important characteristics of insulation material. As shown in Figure 6, perlite had the lowest cost and fiberglass had the highest cost. Figure 6 also shows that perlite has the lowest Cost/k value, and fiberglass, urethane and fiberglass urethane are among materials that have high $C o s t / k$ value.

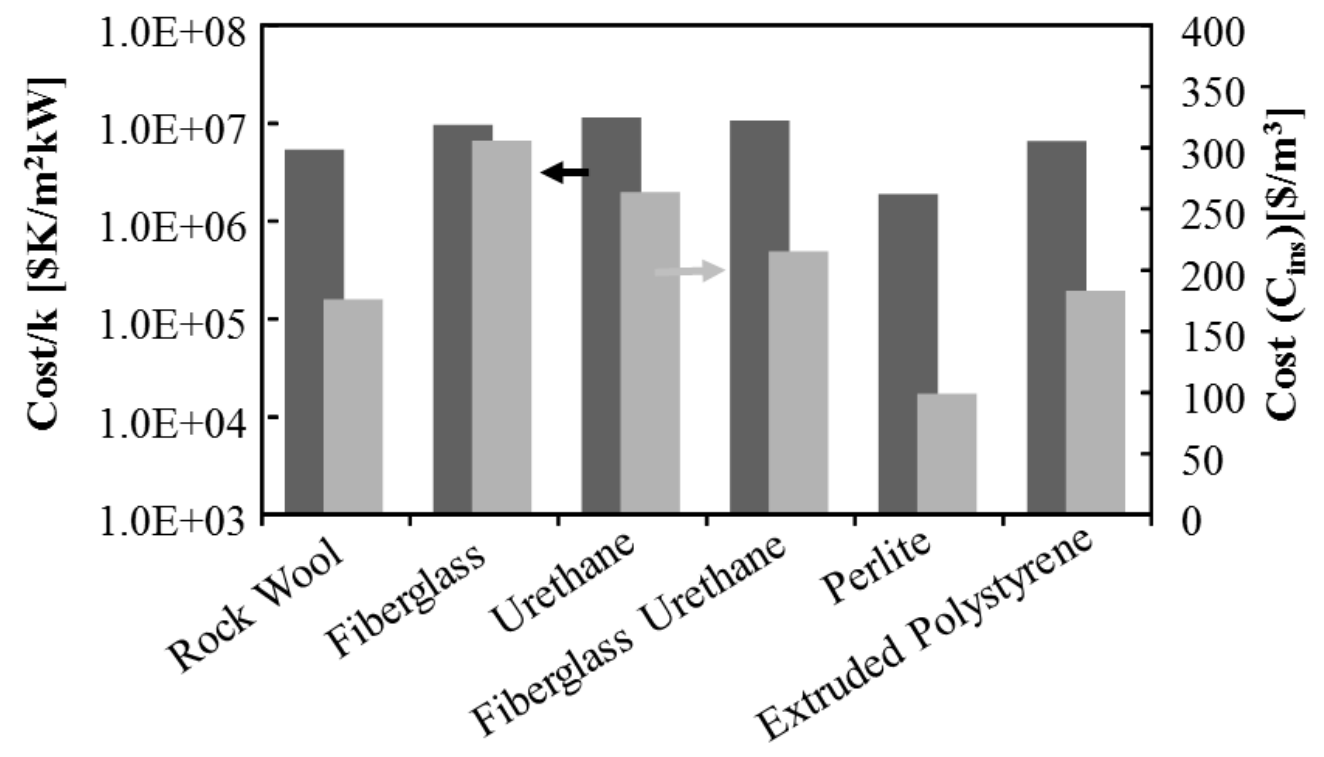

Figure 6. Cost and Cost/k value for all insulation materials.

Figure 7 shows the relation between Cost/k and net saving NS. It was found that the NS increased when the Cost/k value increased. However, when the value of Cost/k was almost the same as the case of fiberglass, urethane and fiberglass urethane, the value of the cost itself affected the NS. For instance, although the Cost/k value was the same at approximately $1.5 \times 10^{7}$ as shown in Figure 7, the $N S$ for material that had lower cost $\left(175 \$ / \mathrm{m}^{3}\right)$ had 3.8 times higher $N S$ than the more expensive material $\left(375 \$ / \mathrm{m}^{3}\right)$. This explains why fiberglass urethane had higher $N S$ than fiberglass and urethane, which had slightly higher Cost/k values than the fiberglass urethane. It can be concluded that a material that has higher Cost/k but lower cost than other materials has the highest $N S$ and is the most cost-effective. 


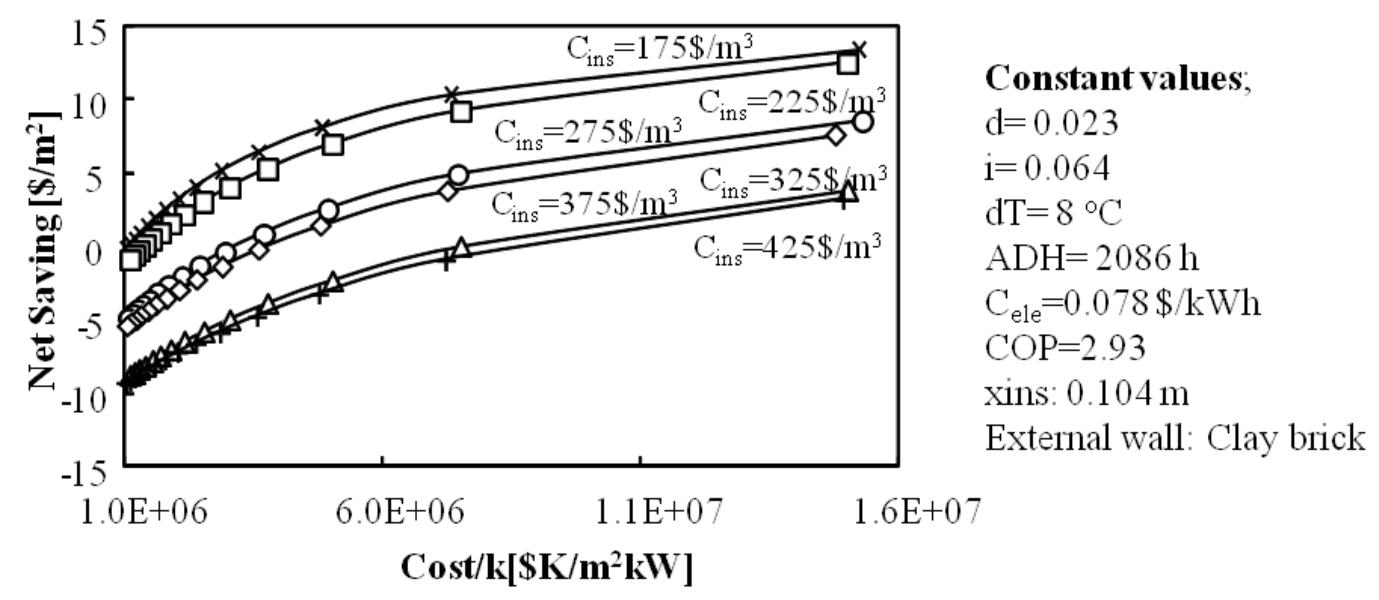

Figure 7. Relation between Cost/k and net saving.

\section{CONCLUSIONS}

The optimum thickness of insulation materials and their performance were studied. It is observed that:

i) Fiberglass has the thinnest optimum thickness, whereas perlite has the thickest optimum thickness for any condition. The range of insulation material thicknesses under the Malaysian climate for all conditions studied was 18-126 $\mathrm{mm}$;

ii) The result for net saving has the same tendency as the result for optimum thickness, in which fiberglass has the lowest net saving while perlite has the second highest net saving;

iii) Different types of building significantly affect the performance of insulation. Building types that have a higher average temperature difference and higher annual demand hours result in thicker insulation and higher net saving.

iv) Different types of external wall that can be represented by their thermal conductivity values only slightly affect the net saving of insulation.

v) Material that has a higher Cost/k value but lower cost than other materials has the highest net saving. Of all the insulation materials studied, fiberglass urethane was the most cost-effective.

\section{ACKNOWLEDGMENTS}

The authors would like to thank Universiti Malaysia Pahang for the financial support under RDU1203101. The first author is grateful for the advice of Mr. Mohd Syawal Jamaludin (Project Manager of TSR Capital Berhad) on wall structures in Malaysia.

\section{REFERENCES}

Al-Khawaja, M. J. (2004). Determination and selecting the optimum thickness of insulation for buildings in hot countries by accounting for solar radiation. Applied Thermal Engineering, 24, 2601-2610. 
Axaopoulos, I., Axaopoulos, P., \& Gelegenis, J. (2014). Optimum insulation thickness for external walls on different orientations considering the speed and direction of the wind. Applied Energy, 117, 167-175.

Chirarattananon, S., Hien, V. D., \& Tummu, P. (2012). Thermal performance and cost effectiveness of wall insulation under Thai climate. Energy and Buildings, 45, 82-90.

Choudhury, B., Chatterjee, P. K., \& Sarkar, J. P. (2010). Review paper on solarpowered air-conditioning through adsorption route. Renewable and Sustainable Energy Reviews, 14, 2189-2195.

Henning, H. M. (2007). Solar assisted air conditioning of buildings - an overview. Applied Thermal Engineering, 10, 1734-1749.

Mahlia, T. M. I. \& Chan, P. L. (2011). Life cycle cost analysis of fuel cell based cogeneration system for residential application in Malaysia. Renewable and Sustainable Energy Reviews, 15, 416-426.

Mahlia, T. M. I. \& Iqbal, A. (2010). Cost benefits analysis and emission reductions of optimum thickness and air gaps for selected insulation materials for building walls in Maldives. Energy, 35, 2242-2250.

Mahlia, T. M. I., Taufiq, B. N., Ismail, \& Masjuki, H. H. (2007). Correlation between thermal conductivity and the thickness of selected insulation materials for building wall. Energy and Buildings, 39, 182-187.

Ozel, M. (2012). Cost analysis for optimum thicknesses and environmental impacts of different insulation materials. Energy and Buildings, 49, 552-559.

Ozel, M. (2013). Thermal, economical and environmental analysis of insulated building walls in a cold climate. Energy Conversion and Management, 76, 674-684.

Pons, M., Meunier, F., Cacciola, G., Critoph, R. E., Groll, M., Puigjaner, L., Spinner, B., \& Zeigler, F. (1999). Thermodynamic based comparison of sorption systems for cooling and heat pumping. International Journal of Refrigeration, 22, 5-17.

Public Works Department Malaysia (2005). Standard Specifications For Building Works (JKR20800-132-23). D/1-E/6.

Yildiz, A., Gurlek, G., Erkek, M., \& Ozbalta, N. (2008). Economical and environmental analyses of thermal insulation thickness in buildings. Journal of Thermal Science and Technology, 28, 25-34.

Yu, J., Yang, C., Tian, L. and Liao, D. (2009). A study on optimum insulation thicknesses of external walls in hot summer and cold winter zone of China. Applied Energy, 86, 2520-2529.

Zhai, X. Q. \& Wang, R. Z. (2010). Experimental investigation and performance analysis on a solar adsorption cooling system with/without heat storage. Applied Energy, 87, 824-835. 